\title{
The COVID-19 Crisis: Implications for the Development and Growth of Agricultural Sector in EU countries and Russia
}

\author{
${ }^{1}$ Baira Faulks, ${ }^{2}$ Song Yinghua \\ ${ }^{1,2}$ School of Management, Wuhan University of Technology, Wuhan, China
}

\begin{abstract}
The COVID-19 crisis impacted negatively sustainable growth and the wellbeing of businesses and national economies. The economic outlook of 2020 and 2021 reflects a slowdown in the global economy, with poverty and unemployment rates ascending, national debts growing, and fiscal and monetary burden increasing. All the sectors of the economy have been affected across all of the EU countries, including the agricultural sector. Coronavirus posed unprecedented challenges for the agricultural sector, ranging from a labour shortage to demand changes. Lockdowns caused immense disturbances in farmers' supply chains, causing them to doubt their long-term viability. Due to the social distancing and restrictions on social gatherings, marketplaces either closed or were devoid of customers. At the same time, the agricultural sector has proved quite resilient during the COVID-19 crisis. In this paper, we discuss the challenges which the agricultural sector has faced during the COVID-19 pandemic, and suggest that further growth and development can be sustained through innovation, more precisely, digital technology. The current conceptual research contributes to the body by exploring the effect of the novel COVID-19 virus on national economies and especially the agricultural sector.
\end{abstract}

Keywords: The COVID-19 crisis, Agricultural sector, Economic implications of COVID-19, COVID-19 in EU countries

\section{Introduction}

In the year 2020, the outbreak of COVID-19 brought severe economic and societal consequences negatively impacting global flows. As well as imposing drastic stress on people, the COVID-19 crisis also disturbed the sustainable growth for the wellbeing of businesses and national economies. Various sectors in the EU have suffered in terms of unemployment, GDP growth and other essential indicators of national development. COVID-19 pandemics outbreak has had a considerable adverse impact on businesses worldwide, with consequences and impaired functionality varying among diverse activities and industries, outcomes of which are yet to be seen in the aftermath. COVID -19 pandemic that brought health problems among people and generated some detrimental effects on the financial situation in food supply chain operations. Clearly, the spheres of agriculture and food supply are currently not a deep crisis; however, agricultural products' prices are getting noticeable higher due to the economic recession in regions. Agriculture and horticulture are closely tied with the notion of food security, a fundamental objective of each nation to achieve unrestricted access to food and water to satisfy peoples' basic needs (Rosales and Mercado, 2020). Major supply chain disruptions precipitated by COVID-19 disease had massive socio-economic implications. The pandemics posed challenges over the last year not just to businesses but also to entire industries breaking the regular supply, demand and delivery, and trading. Obstructions in standard delivery channels imposed additional slowdown of regular revenue-generating processes, such as packaging, distribution and storage. Main agricultural branches include floristry, pot plant, tree nursery, vegetable crop businesses, fruit businesses and farming. Besides output, agriculture is 
an umbrella term encompassing raw materials, agricultural machinery, farms and processing plants, and labour. Agriculture is deemed one of the most basic activities critical for ensuring sustainability (Abdelhedi and Zouari, 2020; Kogo et al., 2020; Siche, 2020). Considering it is closely related to ensuring food security, agricultural industry products are, by definition, the essentials. Contagion hazards related to certain products, food and meat in particular, further slackened the distribution and caused a decrease in the consumption rate. Almost without exception, countries worldwide witnessed negative effects on productivity, sales rates, income and employment. Border closures resulted in interruption of international and cross-border trade, hitting the low-income countries the hardest, decreasing poverty and hunger rates. Ministries around the EU have, during COVID-19, regularly conducted researches and analysis of key business indicators such as turnover and income rates and capital positions to track the changes in agricultural systems. Food suppliers that relied extensively on catering businesses for trade experienced a massive downturn due to hospitality outlets' closure (Wageningen University and Research, 2020). The current research aims to stimulate discussion about the effect of the novel COVID-19 virus on national economies and the agricultural sector. First, we provide a wider context of the economic consequences brought by the COVID-19 pandemic. Next, we focus on the agricultural sector challenges, followed by a proposed solution to innovate the sector. The study aims to fill the existing literature gaps in the field of economic sustainability of the agricultural sectors and the resilience in the time of crisis. Current research aims to address this gap and provide recommendations for the countries and organisations on how to stimulate sustainable performance by focusing on the agricultural sector and minimise adverse effects during the COVID-19 pandemic.

\section{The Review of the COVID-19 Consequences on the Global Economy}

The ominous and disarming effect of prolonged unemployment causes panic, anxiety and depression, consequently perpetuating further job loss. According to the estimates of the impacts of COVID-19 -caused an economic recession and unemployment on mortality and life expectancy, a $3.0 \%$ increase in unemployment-shock related mortality rate and a $0.5 \%$ drop in the life expectancy over the next 15 years is expected, resulting in additional 0.89 million deaths (Bianchi, Bianchi and Song, 2021). When the labour force have experienced a significant stroke, it also translated into fear, uncertainty and insecurity, prompting turnover intention and hindering retention, thus discouraging employees from staying in organisations and engaging with vigorous determination to reconfigure existing processes to accommodate the current condition and create novelty. Furthermore, regarding the expenditure on essentials, it is estimated that over April to June 2020, in comparison with households with employed respondents, households with respondents unemployed due to COVID-19 pandemics closures spent $15 \%$ less on food and are $10 \%$ less likely to have enough food to eat (Raestrepo, Rabbitt and Gregory, 2021). Per capita incomes have decreased in more than $90 \%$ of EMDEs, and projections show that two-thirds of EMDEs incomes will in 2022 fall below the average in 2019. The global economy is facing the deepest recession since the Second World War (World Bank, 2020), with economists arguing that the COVID-19 pandemics has surpassed the 2008 financial crisis. Furthermore, the underinvestment poses a significant challenge as the decline in FDI inflows to EMDEs interfere with capital accumulation (UNCTAD, 2020).

On the global scale, a $5.2 \%$ contraction in GDP is evident despite the introduction of relief packages and governmental interventions. As many economies, especially those falling under the category of low-income-countries (LICS), rely heavily on government aid and relief programmes and initiatives to sustain their operations during the acute phase of virus spread when the restrictions are held firmly, the disastrous consequences of recession have emptied national treasuries. In LICs, activity in 2020 declined by $0.9 \%$, showing a first aggregate contraction in a generation (World Bank, 2021). In Europe, production and services were subject 
to sharp changes. The decrease during the period when most Member States introduced partial or total lockdown and/or restrictions in March and April 2020 was followed by a brief recovery between May and September 2020. According to the Eurostat report, the total service production fell by $9.3 \%$ between February 2020 and September 2020. Industry-wise, the most substantial decline was recorded in tourism, hospitality and accommodation, at a $27.9 \%$ decrease, followed by a decrease in transportation services by $9.6 \%$, administrative and support services by $8.7 \%$, information and communication services by $2.9 \%$ and scientific services dropped by $2.4 \%$ (Eurostat, Impact of the covid-19 crisis on services).

As stated in the Economic Outlook, growth in GDP is anticipated to rise to 3.5 in 2022 following the administration of vaccination. Nonetheless, recovery will take time, and by the end of the forecast horizon, it will remain at 3.2 per cent of pre-pandemic projections (World Bank, 2021).

\section{Agricultural Sector Trends in Russia and EU Countries during COVID-19 Pandemic}

COVID-19 negatively increases the threat of global food emergency as well, leaving a devastating effect on hundreds of millions of people at risk of becoming undernourished. Food insecurity signifies a major global challenge - a lack of access to the critical resource for sustaining humanity. The risk increases with each major disaster affecting income, poverty, and food prices. According to the UN estimates from 2020, as much as 690 million people went hungry in 2019, a 10 million increase compared to 2018. As stated in the report on the State of Food Security and Nutrition in the World, COVID-19 may further push hundreds of millions of people to chronic hunger.

According to the OECD report, pandemics is expected to influence agricultural markets over the following decade, affecting food security, farm livelihoods and trade (OECD, 2020). Furthermore, farmers and agricultural producers have additionally suffered a blow due to customers' decreased financial capacity, which resulted from major layoffs and lockdowns. Monetary aid packages for securing jobs and sustainability were introduced, as well as social programs that served as a buffer to mitigate the negative consequences of the short-term crisis. Most of the spending went to groceries as consumers' focus has shifted from luxury goods to essentials, yet the pre-crisis and during-crises purchasing ratio differed significantly.

Import and export restrictions damaged many suppliers and citizens alike since the ban meant stopping the supply of necessities to the most vulnerable populations. This proved to be a serious challenge. According to the Food Agriculture Organization (FAO), the impact of coronavirus can be classified by its effects as disruption in food demand and food security. Agricultural workers were not excluded from adhering to social distancing measures. When there is no cultivation and farming, there is no production, and lack of production in agricultural business leads to income losses, which many farmers have tried to make up by using the government relief aid packages, and these barely accounted for feeding the cattle to get them through until the relaxation of measures. FAO analysis in the region, most of the issues related to COVID-19 have not been stable but developed with the pandemic. In the first months of the lockdown, there were significant problems in the food supply chain operators regarding insufficient input availability, including labour, transportation, storage, sales and cash flows. The more serious forms of the issues emerged in livestock (including fish), fruits and vegetables, grains, pulses and potatoes. In the EU, most of the seasonal agricultural jobs are accomplished by migrant workers. That is why the countries in the EU eased work permits and extended leaves for people in order to encourage them to stay. Even though governments and operators achieved to cope with the pandemic by easing measures for migrants, another significant problem- a financial issue- has been intensifying. Strick restrictions in domestic markets, to be more precise, the social distancing measures and the temporary closure of wet and livestock 
Baira Faulks, Song Yinghua

The COVID-19 Crisis: Implications for the Development and Growth of Agricultural Sector in EU

countries and Russia

markets negatively affected food producers' work, especially social distancing measures and the temporary closure of wet and livestock markets. The work of hotels, restaurants and catering businesses were stopped or tightened with strong restrictions. This also results in the disruption of food sales in all countries.

In the early days of the pandemic, the main worry among food operators was how to export products to other countries. The majority of the companies oriented to export, such as lamb growers in the Western Balkans and greenhouse fruit and vegetable growers, encountered temporary damages because of the highly strong food safety controls in borders. In June, green lines gave business owners to continue merchandising their products as usual.

In farms, there were early issues related to the availability of seeds and fertilisers, but generous contributors helped to tackle this problem. Another problem was observed in the work of livestock farmers who imported necessary medicines and veterinary products from abroad. Veterinary services (including private providers, where they exist) to conduct surveillance for diseases, provide vaccination campaigns, or respond to epidemic also suffered from the lockdown's negative effects. There are some numbers of farmers informing about the lack of fuel, tools, materials and technical assistance/advisory services.

Retail supply chains in Russian showed higher resiliency than expected. There have been regular droughts and floodings in Russia however climate change is not the primary disrupter for agriculture. The government of Russia concluded to sell grain in its 'intervention reserves' at a lower price, compared to its purchase price level, in order to allow farmers to plant their new crops without any financial loss. It is expected to increase the amount of greenhouse vegetable production by at least $14 \%$ in 2020 . Currently, $45 \%$ of poultry sales in Russia are coming from China, which is predicted to rise in the near future. In Russia, Central Asian seasonal workers are considered the main source of labour for the farming industry. Owing to the Covid 19 pandemic, most of these workers could not enter Russia, which caused the deficiency of the cheap workforce in the agriculture sector. Farmers are afraid of losing their crops; however, it also means the emergency for the agricultural sector and the threat to Russia's food chains. Some Russian experts suggested the government letting migrant workers get into Moscow as early as possible in order to save the harvests.

\section{Impact of COVID-19 on Farming Markets EU Countries and Russia}

According to the Syngenta Group' (Syngenta Group, 2020) research on the status of European farmers during COVID-19 from June 2020, lockdowns caused immense disturbances in farmers' supply chains, causing them to doubt their long-term viability. $46 \%$ of large EU farmers experienced disastrous impacts, making them pessimistic with regards to future sustainability or even viability over the next few years. The most severe effect was recorded in Poland, Spain and Italy, while in comparison situation was moderate in France, Germany and the Netherlands. More than half of surveyed farmers experienced a decline in revenues, sales and supply chain shortages. EU regulations limited their operations during pandemics. For instance, the lack of an active workforce damaged farmers' harvesting and distributing capacity. 
Baira Faulks, Song Yinghua

The COVID-19 Crisis: Implications for the Development and Growth of Agricultural Sector in EU countries and Russia

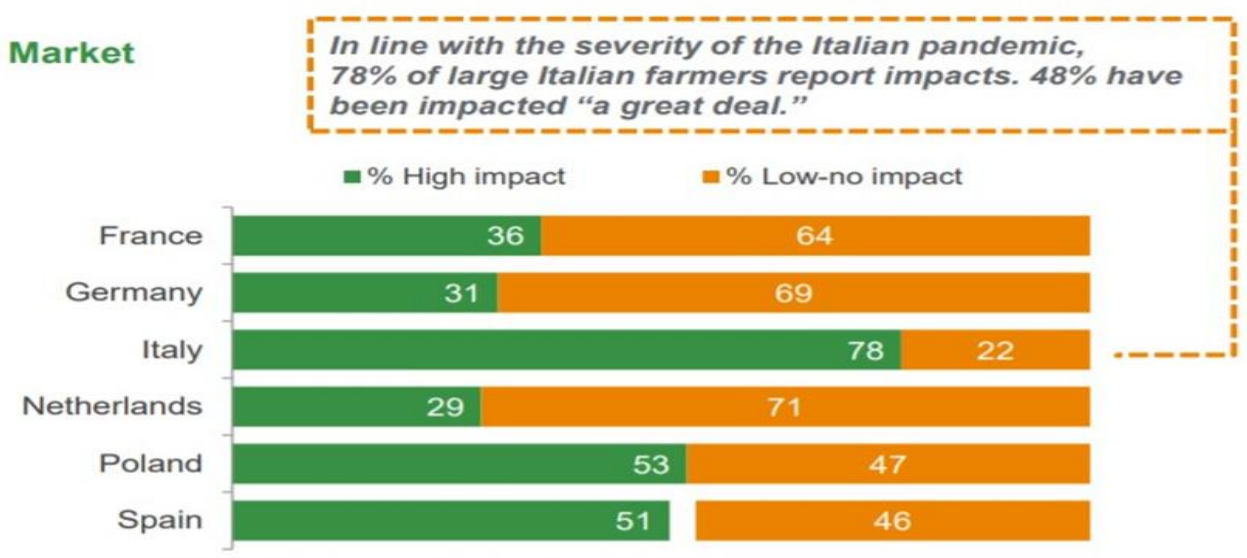

CAUTION: Base sizes are very small here. Country level data is indicative only.

Figure 1: Impact of COVID-19 on farming markets in EU countries Source: Syngenta Group

Reduced demand, market access and prices drive falling revenues; challenges are compacted by labour shortages and inability to move goods

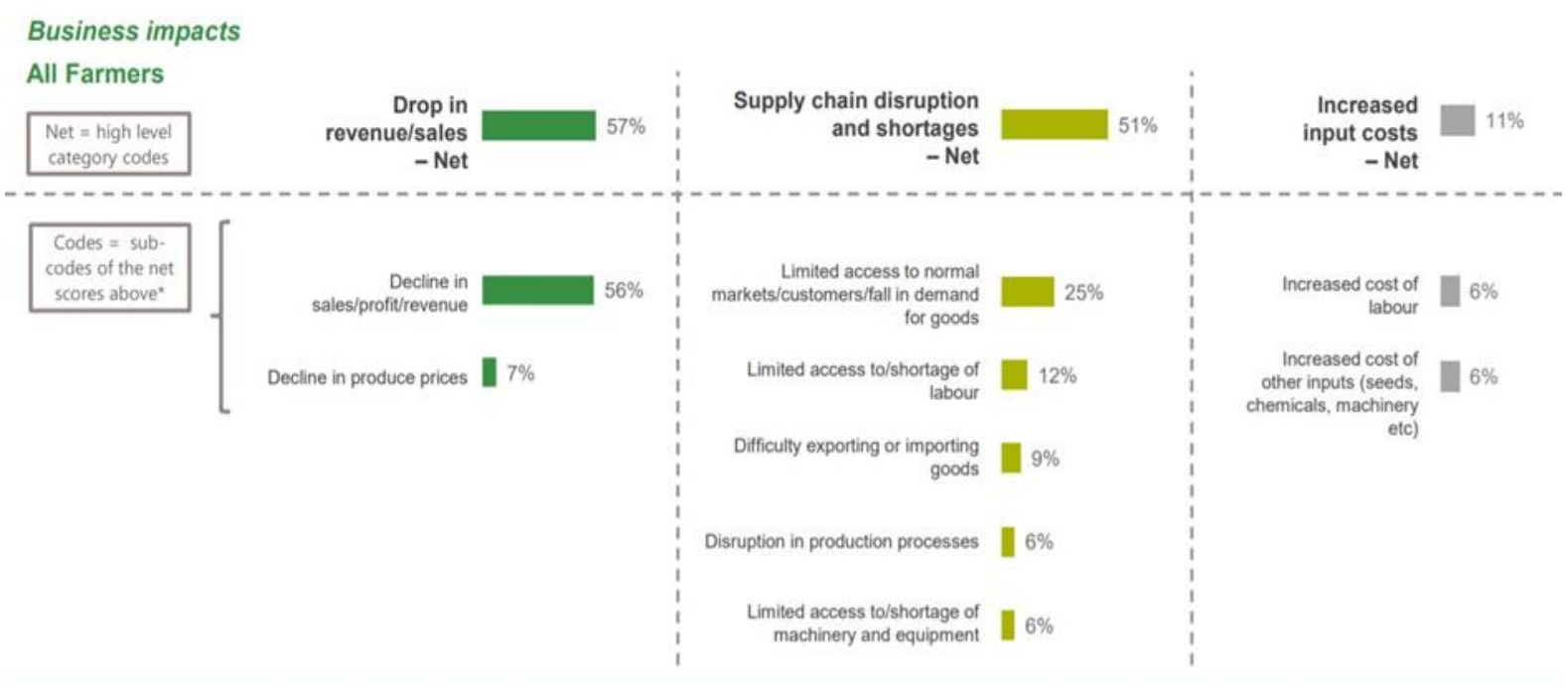

Figure 2: Indicators of COVID-19' impact on the farming business in the EU Member States (in \%)

Source: Syngenta Group

Furthermore, due to the social distancing and restrictions on social gatherings, marketplaces either closed or were devoid of customers, and to many farmers and local suppliers, these markets were the only point of sales. Agricultural workers were forced to come up with alternative distribution channels. Some teamed up with delivery service providers, while others introduced local pick-up points. Although the demand for horticultural products will never seize, COVID-19 prompted temporary shocks throughout the sectors' counterparts. The pandemics brought about shortages of products, distribution disturbances, and inefficiency in regular client supply. The production volume and purchasing levels decreased significantly. The effects varied substantially, ranging from the shortage of essentials to abundant wastages in specific product categories. For instance, fresh products with short shelf life rotted away due to export bans, while the requirement to 'stay at home' and prohibition of gathering impeded the agricultural production reaching its peak in shortage of basic groceries. This was, to some extent, the effect of two conditions - lack of production joint with import layoff. Eventually, the turmoil stabilised 
Baira Faulks, Song Yinghua

The COVID-19 Crisis: Implications for the Development and Growth of Agricultural Sector in EU countries and Russia

due to sectors' relevance in preventing famine, yet not all operation proceeded at the same pace. Food supply is one of the few activities whose maintenance remained a priority for policymakers. COVID-19 perpetuated instability in the agricultural system concerns sudden rises and fall in prices across certain product categories. In accordance with the economic supply and demand law, product availability limitations, especially for food with long shelf life, lead to inflation, while food supply with limited expiry date was sold at unprofitable prices just to avoid deterioration. In Europe, a fall was recorded in the export prices of vegetable oils and meat, while the prices of dairy products increased. Most of the crop was accessible following the proscribed security protocols, notwithstanding the fear of possible contagion. Despite the temporary volatility, prices of necessities remained relatively stable, as measured according to the FAO Food Price Index (FFPI) (Siche, 2020). Effects were greater on the demand end.

According to the EU agricultural outlook 2020-30 report, coronavirus posed unprecedented challenges for the agricultural sector, ranging from a labour shortage to demand changes, yet the general consensus is that the sector proved quite resilient with the EU Commission's aid. The pandemics have led to the dominance of demand for locally produced food, short supply chains and e-commerce. Furthermore, COVID lowered meat and grain prices, while cheese and poultry prices remained stable. For the next decade, agricultural income is expected to rise with production and prices, while the workforce is expected to decline at $1 \%$ per year due to technological progress in machinery. EU meat markets are marked by uncertainty due to shocks and slowdown, as well as due to health considerations; per capita EU meat consumption is likely to decline by $1.1 \mathrm{~kg}$ by 2030 . Domestic consumption declined due to inflation, and regarding exports, the EU is likely to dominate supply, but not to the extent it had in 2019. As per specialised crops, it is expected that post-crisis recovery will lead to export increases.

The Russian budget earned $\$ 25$ bn in 2020 by exporting grain to other countries. Additionally, Ukraine went through a drought, which caused the increase of the global market price. The development of the agriculture sector is connected with the Kremlin's decision, which imposed tit-for-tat sanctions on the EU. This action became the main driving force for agriculture to grow after the EU prohibited to import of all agricultural products to Russia. That is a good opportunity for the government to direct huge amounts of investments into the agriculture sector in order to make the country independent. Russia also developed the cheese production industry, which did not exist before, including the manufacture of "Siberian camembert". Russia agriculture production volume and change can be seen in figure 2.

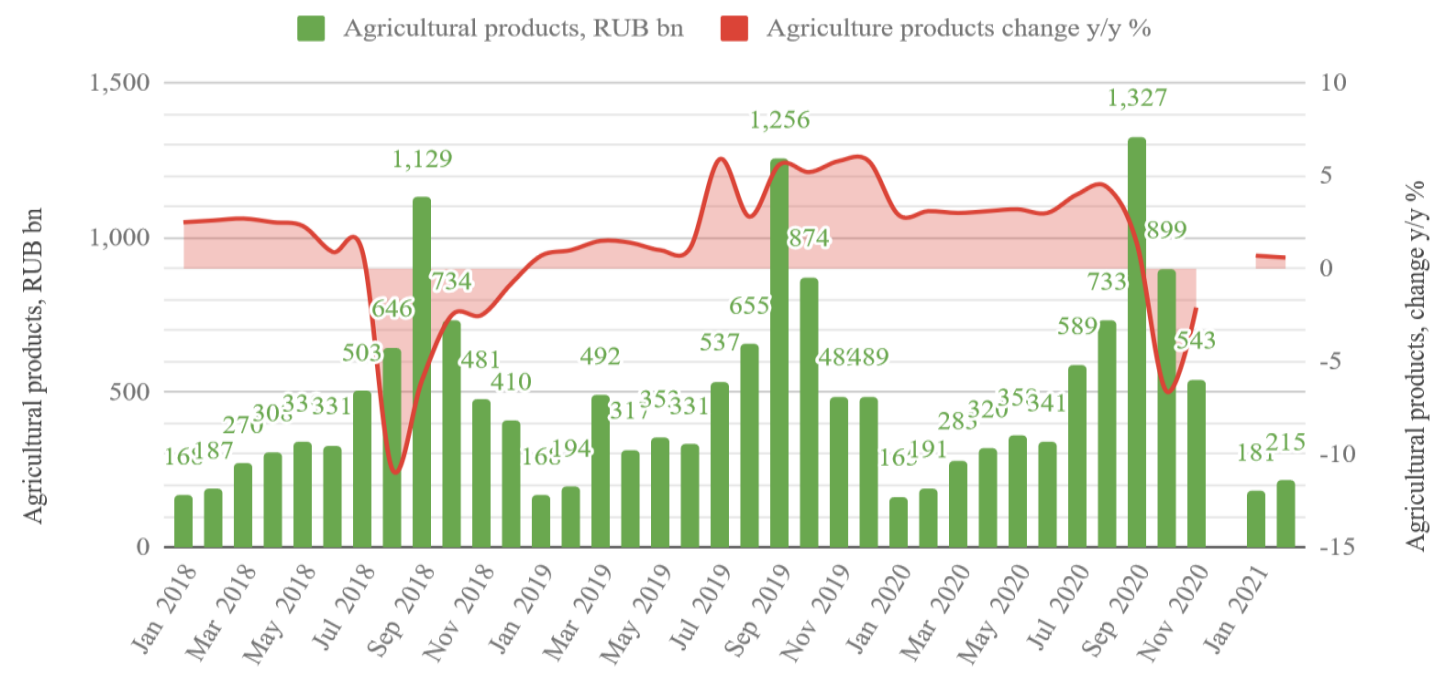

Figure 2: Russia agriculture production volume vs. change 
Baira Faulks, Song Yinghua

The COVID-19 Crisis: Implications for the Development and Growth of Agricultural Sector in EU countries and Russia

The production level in agriculture has been growing year by year in the last few decades. Despite the severe damage from the Covid 19 pandemic, the agricultural output showed an upward trend with 1,5\% slower than the previous years. The primary aim of Russia is to become the "world's biggest grain exporter" in comparison with Ukraine. That could be because the government is trying to increase the output of grain with different agricultural reforms. Russia successfully achieved to raise the production level of grain by $10 \%$ last year at $133 \mathrm{mn}$ tonnes and $43 \mathrm{mn}$ tonnes of exports. Figure 3 depicts Russia grain production export in metric tons. This amount is near the record harvest of $135.4 \mathrm{mn}$ tonnes in 2017. Conversely, there have been difficulties for other subsectors of agriculture. The production of particular crops(potatoes and sugar beet) decreased significantly to the level which was not seen in the last few years. As a result, the price of sugar skyrocketed by $75 \%$ in the last quarter of 2020 , which led the Kremlin to control the basic products' price. This regulation is still in place and will continue for the next six months. According to the statistics of the Bank of Finland Institute for Economies in Transition (BOFIT), the agricultural output of crop showed a considerably slower increase compared with the recent years. Private farmers contributed significantly to crop farming in Russia. That is why private farmers' share in crop yielding increased to more than $20 \%$ of the total national production.

Grian production $\mathrm{m}$ tonnes

Grain export marketing year (July 1 of same year - June 30 of next year) $\mathrm{m}$ tonnes Grain harvest forecast official

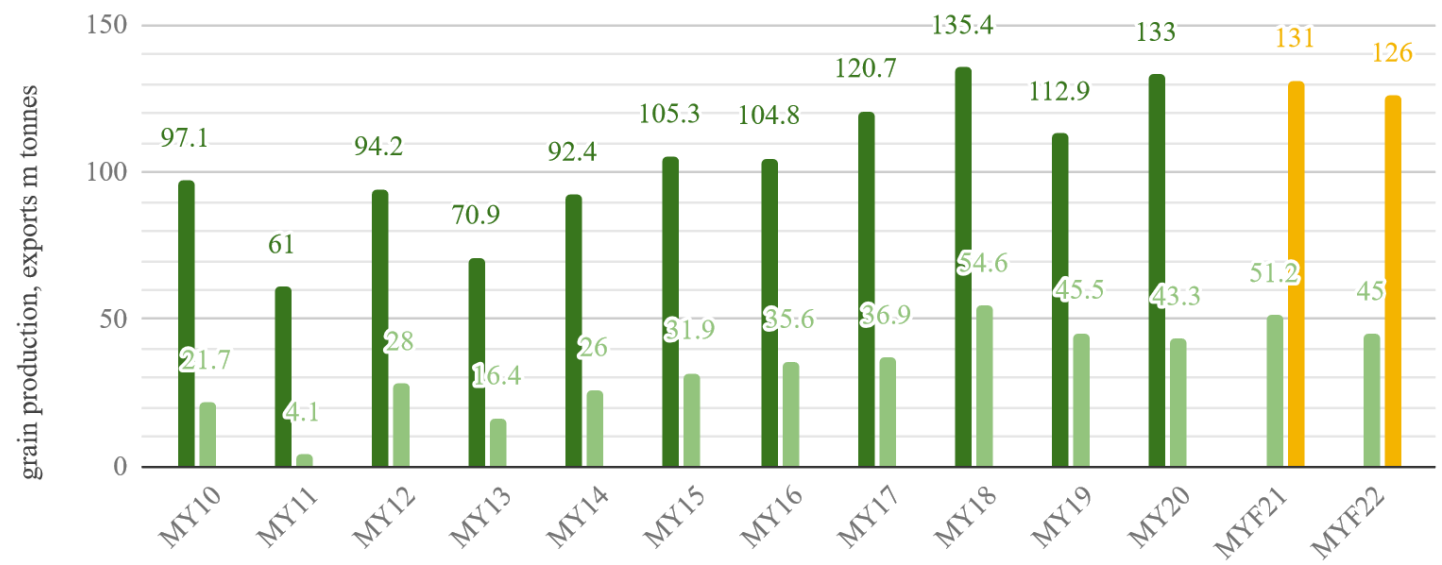

Figure 3: Russia grain production export $\mathrm{m}$ tons

\section{Agricultural Development and Growth through Digital Innovation}

With some of the industries collapsing under the pressure, and others thriving with staggering success, international collaboration is established among different domain experts to isolate and determine the critical success factors that can affirm national and organisational resilience and ensure sustainability. The agricultural sector organisations impeded by face-to-face interaction and physical gatherings brought to the fore the need for organisations to undergo the digital transformation. Accordingly, with the knowledge concerning the benefits of ICT and digital advances, even before the crisis, many EU countries have emphasised the need to create and foster a digital society. This need became even more pronounced under the peril of COVID-19 pandemics, especially considering the challenges new restrictions have posed for education, business, and healthcare. The majority of public institutions and private organisations and service providers have transitioned to an online model, reducing the unnecessary bureaucracy 
Baira Faulks, Song Yinghua

The COVID-19 Crisis: Implications for the Development and Growth of Agricultural Sector in EU

countries and Russia

and administrative activities and providing services in a new e-environment while respecting the need for social distancing. With the stoppage of exhibitions and traditional markets, farmers need to find novel ways to serve their customers. It is plausible that following the emergent and supervening way products are transformed and adjusted to new situation carries the legacy for the inception of future products and services post-crisis, their content being explicitly designed to be delivered online (José García-Peñalvo et al., 2021).

During the past year, we have already witnessed COVID-19 state-of-affairs yield cases of successful practices. The common denominator in all success stories boils down to novelty in adopting the advanced labour-saving technology for collecting, acquiring, sharing and processing data, which allows for a more customised approach of responding to market shocks. To achieve innovation, all employees should maintain continuous communication and information exchange regarding the current situation, emergent changes, possible solutions and keep their actions aligned even when they are not sharing the physical environment. Meaning, the integration of ICT advanced tools, platforms and communication channels is not an advantage but a precondition for an organisation to survive and mitigate the harmful effects of the crisis. In conducting 'emergency' operations, cyber structure, information management systems, knowledge management systems, and IT infrastructure should already be in place, and as numerous previous studies have shown (Lopez, 2018; Robey et al., 2002), lacking hardware or soft skills, i.e., technological proficiency can be detrimental for enterprises (Tomasini \& Van Wasserhove, 2009). Such systems have been seldomly used by agricultural producers and even less by farmers. The successful implementation of such technology and processes would help meet challenges farmers face, and the agricultural sector would become more resilient to the current COVID-19 pandemic circumstance. Farmers that ha decline in revenues and sales due to limited reach and distribution channels would, through digital innovation, be able to serve existing markets and even enter new ones. Processing, storing, sharing, distributing and reusing data in the sphere of agricultural becomes crucial for conceiving innovative ideas. However, the level of acceptance of such technology by farmers depends on the learning readiness; wherein all employees should be educated, open-minded, engaged and invested in learning how to navigate the new online model successfully. According to Usluel et al. (2008), ICT usage can serve as the measure of acceptance, adoption, and application of innovation. The primary obstacle in enterprise digital transformation is the pre-existing structure in terms of organisational systems limitation, lack of knowledge on how to implement new technology, and inherited habitual routine behaviour causing employees to resist changes (Alvarez and Urla, 2002). Hence, harnessing the benefits from ICT adoption relies not solely on aligning the organisational processes with new systems, but more importantly, on the personorganisational fit (Teo and A. Bhattacherjee, 2014). The technological context of the new business environment encompasses employees' ICT skills and infrastructure (Ahn and Ahn, 2020). According to Lutovac and Mnojlov, when employees lack essential ICT skills, their stress levels increase and motivation to learn decreases. They are either reluctant to persist and resume training, or they overtly resist change, thus causing financial and infrastructural costs. This is a huge challenge for the agricultural sector to overcome due to the fact that many of the agricultural producers are micro and small-medium enterprises. For that reason, government support and programs for introducing digital technology during COVID-19 are crucial for farmers to transition from a brick-and-mortar model of operating to the digital economy.

\section{Conclusion}

The recovery is looming as vaccination is developed and being procured and distributed at the moment, but it will be a slow and demanding process. As the crisis is evolving, more precise projections of the upshot, resilience and status of the global economy can be made. The economic outlook of 2020 and 2021 reflects a slowdown in the global economy, with poverty and unemployment rates ascending, national debts growing, and fiscal and monetary burden increasing. COVID-19 also increased the threat of global food emergency, leaving a devastating 
Baira Faulks, Song Yinghua

The COVID-19 Crisis: Implications for the Development and Growth of Agricultural Sector in EU countries and Russia

effect on hundreds of millions of people at risk of becoming undernourished. Food insecurity and the development of the agricultural sector is a challenge both in EU countries and across the globe. The government should consider agriculture as an engine to rebound the economy.

\section{References}

- Abdelhedi, I.T.; Zouari, S.Z. (2020). Agriculture and Food Security in North Africa: a Theoretical and Empirical Approach. Journal of the Knowledge Economy (in press).

- Asare, P., \& Barfi, R. (2021). THE IMPACT OF COVID-19 PANDEMIC ON THE GLOBAL ECONOMY: EMPHASIS ON POVERTY ALLEVIATION AND ECONOMIC GROWTH. Economics. $\underline{\text { Crossref }}$

- Bianchi, F., Bianchi, G., \& Song, D. (2021). The Long-Term Impact of the COVID-19 Unemployment Shock on Life Expectancy and Mortality Rates. National Bureau of Economic Research. CrossRef

- Blake, P., Wadhwa, D. (2020). Year in Review: The impact of COVID-19 in 12 charts. World bank blog.

- COVID-19 Impact Research European Farmers (2020, June). Syngenta Group.

- EC (2020), EU agricultural outlook for markets, income and environment, 2020-2030. European Commission, DG Agriculture and Rural Development, Brussels.

- FAO - Food and Agriculture Organization. 2020a. Q\&A: COVID-19 pandemic - impact on food and agriculture.

- $\quad$ FAO - Food and Agriculture Organization. 2020c. FAO Food Price Index.

- García-Peñalvo, F. J., Corell, A., Rivero-Ortega, R., Rodríguez-Conde, M. J., \& RodríguezGarcía, N. (2021). Impact of the COVID-19 on Higher Education: An Experience-Based Approach. In Information Technology Trends for a Global and Interdisciplinary Research Community (pp. 1-18). IGI Global. CrossRef

- Global Economic Prospects. (2021). A World Bank Group. Flagship Report.

- Global Economy to Expand by 4\% in 2021; Vaccine Deployment and Investment Key to Sustaining the Recovery. The World Bank press release.

- How COVID-19 Has Affected the Agriculture Industry (2020). Industry today.

- Impact of Covid-19 crisis on services. (2020). Eurostat report.

- Impact of the coronavirus pandemic on the global economy - Statistics \& Facts. Statista Research Department, Nov 20, 2020.

- Kogo, B.K.; Kumar, L.; Koech, R. (2020). Climate change and variability in Kenya: a review of impacts on agriculture and food security Environment, Development and Sustainability (in press). CrossRef

- OECD (2020), "The impact of COVID-19 on agricultural markets and GHG emissions", OECD Policy Responses to Coronavirus (COVID-19), OECD Publishing, Paris. CrossRef

- Policy responses to COVID-19. IMF.

- Research into the impacts of COVID-19 on the agriculture sector. Wageningen University \& Research.

- Restrepo, B. J., Rabbitt, M. P., \& Gregory, C. A. (2021). The Effect of Unemployment on Food Spending and Adequacy: Evidence from Coronavirus-Induced Firm Closures. Applied Economic Perspectives and Policy. CrossRef

- Siche, R. (2020). What is the impact of COVID-19 disease on agriculture? Scientia Agropecuaria. CrossRef

- The Global Economic Outlook During the COVID-19 Pandemic: A Changed World. (2020). The World Bank.

- Vitenu-Sackey, P. A., \& Barfi, R. (2021). The Impact of Covid-19 Pandemic on the Global Economy: Emphasis on Poverty Alleviation and Economic Growth. The Economics and Finance Letters. CrossRef

- Oxford Analytica (2020). Russian farming thrives despite COVID-19 and drought. Expert Briefings. CrossRef 